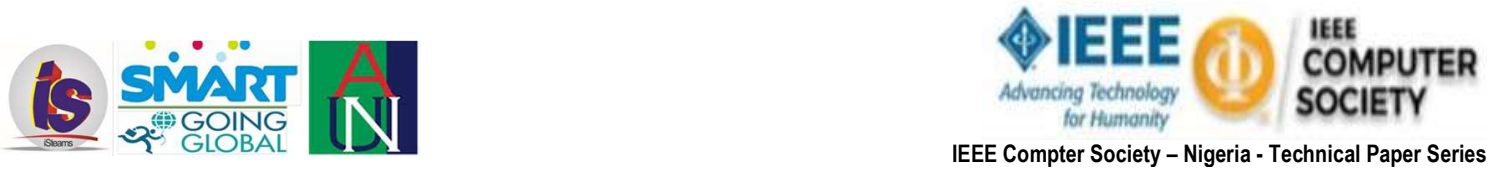

\title{
Effective Green Human Resource Management and Corporate Social Responsibility Strategy for Sustainable Development in the 21st Century
}

\author{
W.D. Olanipekun (PhD) \\ Dep of Mgt \&Acct \\ Summit University \\ Offa, Nigeria. \\ wahidolanipekun \\ (a)gmail.com \\ 08064432887
}

\author{
L.O. Olanipekun \\ Dept of Ind. Relations \\ Lagos University, Ojo, \\ Lagos, Nigeria \\ olanipekunokikiolalateef@ \\ gmail.com \\ 08113401356
}

\author{
A.G. Bamidele $(\mathrm{PhD})$ \\ Dep of Bus \& Entrepreneurship,
Nigeria
ayodejibamidele1@gmail.
com \\ 08038132230
}

\begin{abstract}
Corporate social responsibility is an activity embarked upon by organisations as a way of giving back to the society what was previously deposited in the organisation's coffers as revenue. In the same vein, environmental challenges in the $21^{\text {st }}$ century brings to the fore, a new approach which allows all hands to be on deck to ensure effective CSR geared towards sustainable development. This event birthed the concept of green human resource management which was examined vis a vis CSR as tool for the realisation of sustainable development in the $21^{\text {st }}$ century. This paper gives a clear understanding of how effective GHRM and CSR strategy can drive sustainable development. The study concluded that premium should be placed on the human capital of every organisation using the GHRM framework; this will not only motivate employees to become partners in progress, it also bestow upon them a huge sense of responsibility that will assist organisations to succeed in their CSR activities which will have a long lasting positive effect on sustainable development.
\end{abstract}

Keywords: GHRM, Corporate Social Responsibility, Sustainable Development, Organisations

\section{INTRODUCTION}

Human activities overtime have negatively affected ecology, weather and the environment; these activities have brought about calamitous consequences which require urgent attention, if the environment texture must be sustained. As advanced by Alvarado and Toledo $\{1\}$ as economic activities increases, its significant effect dampens and degrades the environment thereby causing ecological calamities and disaster; thus, creating a kind of unnatural change in our weather.
Overtime, the world is experiencing a negative change in her atmosphere and this change is a continuum, so a modality is required to help keep the environment from being further degraded. Based on the foregoing, a consensus has emerged from all nations across the world on how to proactively manage the environment towards sustainable development. To achieve this, organisations globally have been charged with the responsibility to effectively engage the most importantpart of their resources (employees) through corporate social responsibility in managing the environment [3].

Since organisational activities affect both human and nature at the same time; solution must be devised by both public and private organisations on environmental issues. In seeking the way forward on the above identified challenge, green human resource management (GHRM) was brought to the fore as an effective tool for ensuring and realising sustainable development. The concept of sustainable development which was a core mandate enshrined in the SDG goals; vision 2030 was borne out of continuous environmental depravity which is characterised by organisational activities and exploitation. To curb this menace, management of organisations have expanded their culture and framework by including environmental management strategies into their vision and mission statements and human resource activities. This is done in a bid to contribute their quota in terms of corporate social responsibility using the green human resource management (GHRM). 
This is because employees' (Human Resources) are the propellers of change towards environmental management for sustainable development. GHRM is a regarded as an act of embedding or blending HRM activities with environmental management strategies [9] [26]. From the above definition, GHRM implies the act of creating an environmental-friendly HR practices by organisations to achieve corporate social responsibility objective in the area of mitigating and combatting negative environmental impacts encountered as a result of the actions, inactions and policies of management [11] [25].

Corporate social responsibility (CSR) on the other hand is a continuous process embarked upon by an organisation to contribute ethically towards developing the economy while bettering an organisation's environmental life, the workforce, immediate community and society at large [30]. Activities of CSR follow two folds which are the internal and external.

The internal fold or dimension incorporates consumers, corporations, employees, and consumers while the external fold deals with communities at the local level, and environmental issues [7]. From the above statements, it is apparent that GHRM and CSR are essential ingredients for realising sustainable development in the $21^{\text {st }}$ century; thus effectively synergising these concepts would go a long way in assisting organisations to efficiently discharge their corporate duties towards greening the environment by effectively engaging their human resources.

Furthermore, organisations have realised the importance and benefits of practising CSR; it enables the organisation to give back to their stakeholders while at the same time, making progress in their business interests [31]. Employees are one of the most important stakeholders of an organisation because they can be influenced by and also influence the organisations' activities; thus playing an all encompassing role in organisational effectiveness. Mirfazli [19] opined that CSR practices can attract and retain the best workers in any organisation.

Also, the extent to which employees participate and involve in CSR initiatives of an organisation would determine its success. Strandberg (2009) opined that employees are in a strategic position to nurture and foster CSR performance within their organisations. They are positioned to implement CSR initiatives that will benefit both the company and its stakeholders [16].
Jonikas [13] stated that employees by virtue of been a key stakeholder of the firm should not be seen as cost to be managed, but as an asset to be developed and valued. Rupp, Ganapathi, Aguilera, and Williams [24] opined that despite the germane roles of employees, among diverse groups of stakeholders, the perception of employees with respect to CSR acts are less emphasized on with little or no attention. This seems ironic as the employees make up the life blood of the organisation. The employees are the ones who directly witness, perceive and evaluate the CSR activities carried out by their organisations.

The employee as an important key in an organization, needs a good motivation that will make them work well. Hence, it becomes important to study various factors associated with corporate social responsibility from the employee's perspective. The failure to carry out social responsibilities will cause more harm to a business than good because social and ethical responsibilities do attract and retain the best workers in any organisation [19]. Increasing concerns have emerged globally on the revitalization of the environment and this has put organisations under pressure to prioritise their environments through their business practices to ensure its sustainability [27].

Also, several studies have been conducted on different areas and dimensions of Corporate Social Responsibility and its significance towards economic development. However, none of these studies have been able to synergise both green human resource management and corporate social responsibility especially in the Nigerian manufacturing sector. Even though existing literature housed topics from both concepts (GHRM and CSR), literatures integrating them together for environmental management and sustainability in Nigerian manufacturing sector is still inadequate. It is the contention of this study to carry out a conceptual exposition on the how Green Human Resource Management and CSR strategy can serve as a panacea for sustainable development which the $21^{\text {st }}$ century demands.

\section{LITERATURE REVIEW}

\section{CONCEPTUAL REVIEW}

\section{A. Corporate Social Responsibility (CSR)}

The increasing global interest and discourse on CSR has led to several changes in the way corporate organisations do business in the global market. Different strategies, tactics and policies are now employed with respect to efficient facilitation and interaction among societal needs, the natural 
environment and corresponding business imperatives. While many organisations are adopting a range of voluntary initiatives associated with improvement in working conditions, environmental performances and company relations with workers, consumers, local community, and other stakeholders, others continue to wrestle with the challenges of integrating economic, social and environmental expectations of their stakeholders into the overall business operations [22]

According to Global Reporting Initiative [8], thousands of organisations worldwide now produce sustainability reports. Similarly, KPMG International Survey of 2011 which covers 34 countries (Nigeria inclusive) shows that 95 percent of the 250 largest global companies now report on their corporate responsibility activities. This is in response to the demand for organisations to be more transparent in how they treat their economic, social and environmental activities to positively affect their stakeholders.

The World Business Council for Sustainable Development [30] perspective of CSR is quite different. The definition emphasises on the need for businesses to contribute to economic development through practices that are ethically compliant while also improving significantly the standard of living of the organisation's employees and the society at large. Corporate social responsibility (CSR) is a business concept whereby a company seeks to behave in socially and environmentally responsible ways so that its business contributes to society in meaningful and lasting ways [10].

Chandler (2001) stressed that while there is no universal definition of CSR, it refers to transparent business practises that are based on ethical values, compliance with legal requirements and respect for people, communities and the environment. Mate (2002) sees CSR as having five themes (human rights, workers' rights, environmental impact, community involvement, and supplier relations and monitoring). These themes must reflect in the company core values and impinge on its policies, strategies, decisionmaking and operations. Organisation for Economic Cooperation Development [20] posits that CSR is very similar to the concept of corporate sustainability which remarks the integration of economic and social issues to business managements, and in that way a sustainable strategy is developed in the long term.

\section{B. Green Human Resource Management (GHRM)}

GHRM is a process that involves the act of employing friendly human resource initiatives to greening the environment for the sake of organisational effectiveness and cost reduction, through employee engagement and participation to ensure retention. GHRM has varieties of functions in the HR Department. It helps in the area of paper reduction, usage and creates initiative HR policies in terms of recruitment, selection, planning, and employee management as well as employee relations. Peter and Lanos [23] from their views defined GHRM as an initiative for waste reduction. GHRM helps in greening the workspace to avoid depravity [21]. To this end, all activities and programmes embedded in GHRM helps in enhancing not only the values of the employees but that of the organisation as well.

Currently, the pertinence of GHRM is evident globally. The consciousness of maintaining an ecological balance has become a drive for enhancing human life style towards the environment. Thus, employees should be made to be interested in the practice of GHRM because of how significant it is for environmental sustainability and an avenue for ensuring corporate social responsibility. Corporate organisations are the most significant tool for revitalizing and enhancing the environmental; because of this reason, corporate social responsibility from the corporate world has become a solution to enriching the environment. 


\section{5 sininist IN \\ IEEE Compter Society - Nigeria - Technical Paper Series}

\section{CONCEPTUAL FRAMEWORK}

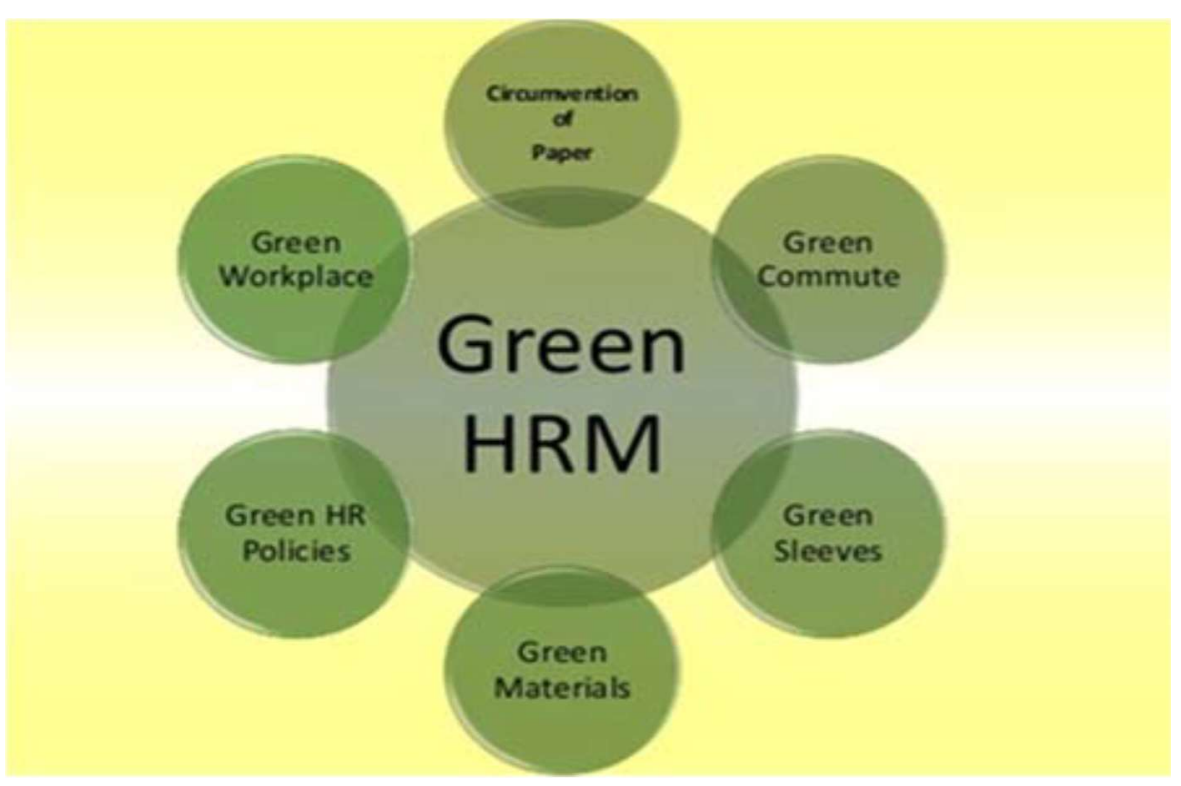

Fig 1: GHRM is a Part of CSR Activity

Source: www.greenbusiness.com

To implement any corporate environmental program, several units of an organisation such as human resource, marketing, finance, operations are put together. But the major part lies to the human resource department as corporate social responsibility (CSR). Though, green HRM is the wider programme of corporate social responsibility because in any organisation, the human resource and their systems are the basic foundation of any business. The green human resource management consists of two major parts of an organisation.

The environment friendly human resource practices and preservation of knowledge capital is considered as green human resource management elements. Green HRM as transforming the usual employees to green employees to achieve the environmental organisational goal and as to solve the environmental issues. The green human resource management involves all the activities in the organisation such as on-going maintenance that makes the employee green

\section{COMPONENTS OF GHRM}

\section{A. Green Recruitment}

Green recruitment means paper free recruitment process with minimal environment impact. Green recruiting is a system where the focus is given on importance of the environment and making it a major element within the organisation. In their study on turnover and retention of employee argue that the most important benefit dimensions of human resource and sustainability are retention and satisfaction. organisations are now beginning to recognise the fact that gaining reputation as a green employee is an effective way to attract new talent.

The green recruiting is a system where the focus is given on importance of the environment and making it a major element within the organisation. Complementing this recruits are also enthusiastic and to some extent passionate about working for an environment friendly green company. Recruiting candidates with green bend of mind make it easy for firms to induct professionals who are aware with sustainable processes and are already familiar with basics like recycling, conservation and creating more logical world. 
Through the statements we can conclude that green recruitment provides the employer with an opportunity to stand ahead of the crowd and further increase their chance of attracting the candidates and retain them after induction. Recently, the green trend makes the recruitment as environmental friendly issues. Recruitment process makes an employee green in achieving the environmental goals and how they perceive the job and parameters of sustainability as claimed.

For example the recruiting can be done as paper less interviews, eco-friendly locations and also other practices in the recruitment portfolio. The recruiters can carry out the green policies as well as the corporate policies in the management in establishing green policies to achieve the goals of the company.

\section{B. Green Training and Development}

The green training and development is a practice that focuses on development of employee's skills, knowledge and attitudes. The green training and development educate employees about environmental management and training should be given for the employees to educate also about energy, reduce waste, and diffuse environmental awareness in the organisation. This green training and development helps employees to provide opportunity to engage employees in environmental problem solving. Green training and development activities make employees aware of different aspects and values of environment management. The green training embraces different methods of conservation including waste management within an organisation. The best management practices concluded that environmental training and education along with establishing a favorable environmental culture for the employees where they feel that they are the part of the organisation.

Further the green human resource practices enhance the skill of an employee to educate with the different environmental issues. This study involves in role of human resource practices to develop the leadership among mangers through workshops and the behavioral competencies and the teamwork practices will improve among them. Through this training session, it develops the eco-friendly mangers so that employees under supervision can contact them without any hesitation. Through this study, we can conclude that we can train employees on best business practices with green initiatives.
So this will enhance the organisation and in person as well. Moreover the employees can educate their customers about the advantages on becoming earth friendly and buying green products.

\section{Green Employee Relations}

In human resource management, the employee relations are one of the important aspect to establishing good natured employer and employee relationship. Through employee relations, the motivation and morale of individual employee will be increased and it would enhance empowerment activities. The green human resource management also helps to recover and determine the troubles arisen at place of work that may influence the effort. In detail, optimistic employee relations are an indescribable and continuing advantage and a source of aggressive improvement for any organisation. Employee contribution in Green initiatives increases the probability of superior green management as it aligns employee's goals, motivations, and perceptions with green management practices and systems.

\section{CONTRIBUTIONS OF GHRM TOWARDS EFFECTIVE CSR}

Many employers now recognise that green programmes in the organisation can aid the promotion of social responsibility among employees and help retain top talent. Many green companies boast of low employee turnover rates compared to their nonsustainable counterparts. This has also been empirically discovered from the results of various surveys, which state the several advantages of having a green workforce. These are:

i. Environment-friendly business decisions: Having employees who understand the importance of sustainability enables business to make decisions with a broader perspective that helps bring about innovative solutions to pressing and/or emerging environment-related problems, issues.

ii. Desirability as an employer: Green employers become the most preferred choice of green talent pool, i.e. potential employees who not just understand sustainability but have also put it in practice in business previously. Green workforce gives the company a competitive edge.

iii. Employee retention: Green organisations are known to have lower turnover rates compared to their non-sustainable 
counterparts as found out from the SHRM Green Workplace Survey 2. 61\% of respondents working for an environmentsavvy company said they were "likely" or "very likely" to stay at the business because of the practices.

iv. Improved sales: According to the findings of the 2009 Cone Communications Green Gap Trend Tracker Survey $4.71 \%$ of Americans consider the environment when they shop. The findings of this survey reinstate that good environment management practices followed by companies go a long way; it can improve sales and reduce costs.

\section{A. Triple Bottom Line Dimension of CSR (Sustainable Development)}

The concept of sustainable development is generally regarded as having emerged from the environmental perspective which emphasizes on how to manage physical resources so that they are conserved for the future. The Brundtland report of 1987 is one of the often quoted definitions of sustainable development. Sustainable development is "development that meets the needs of the present generations without compromising the ability of the future generations to meet their own needs (World Commission on Environment and Development, WCED 1987). Elkington [6] coined 'triple bottom line (TBL) as a new term to advance his sustainability agenda. He wrote: "Sustainable Development (SD) involves the simultaneous pursuit of economic prosperity, environmental quality, and social equity.

The companies aiming for sustainability needs to perform not against a single, financial bottom line but against the triple bottom line (Elkington, 1998). Elkington's definition intended to go beyond previous constructions of SD and CSR to encompass an approach that emphasises economic prosperity, social development and environmental quality as an integrated method of doing business. Thus, businesses should not only consider the economic interests, but has to consider integration of the societal issues such as the environment and social welfare if they are to survive in the long-term. Generally, Sustainable Development is understood as the "process of achieving human development in an inclusive, connected, equitable, prudent, and secure manner" [8] [22].
Sustainability is about ensuring long-term business success while contributing towards economic and social development, a healthy environment and a stable society [2]. It is about being able to deliver positive impact to society while protecting the communities and environment in which the business operates. The Institute of Directors of South Africa [12] added that sustainability is the primary moral and economic imperative of the 21 st century.

It is one of the most important sources of both opportunities and risks for businesses since nature, society, and business are interconnected in complex ways that should be understood by decision-makers since organisations have to align their products and services with stakeholder expectations, thereby adding economic, environmental and social value.

The triple bottom line emphasizes that business firms do not only have one objective, profitability, but that they also have objectives of adding environmental and social value to the society 14]. Marrewijk and Werre [17] refer to company activities involving economic, social and environmental concerns in business operations. These three elements are often referred to as triple bottom line [32].

\section{CONCLUSION AND RECOMMENDATIONS}

GHRM is a set of policies which motivates a green workforce and helps them understand the green culture that is ingrained in an organisation. The green initiatives can be implemented in all HR practices in areas such as recruiting, hiring, training, compensation, development and improvement of an organisation's human capital. GHRM plays a significant role within the organisation and they can translate HRM policies into human capital and enhance employee engagement, incentive compensation, selection processes, and performance management systems for organisational success.

GHRM is a new area for rapid development which assists in increasing the likelihood of achieving and maintaining organisational strategy towards greening the workspace. Thus, recruitment, training, employee motivation and so on are important agents and organisational dimensions to develop effective employee engagement in green management principles for the enhancement of CSR.

This is because today, increasing number of individuals that give importance to issues related to social responsibility, the implementation of CSR strategies in one company, not only creates a better working environment, but makes easier to recruit new 
highly-skilled workers because its enhanced image attract an increased number of requests for employment.

CSR is an important factor for employee motivation and in attracting and retaining top quality employees. Innovation, creativity, intellectual capital and learning are helped by a positive CSR strategy. Given that 80 per cent of the value of many new economy companies is now their intellectual capital, its preservation through the positive treatment of internal stakeholders is becoming more and more necessary. This study identifies and explains in clear term the specific functionality of HR activities with natural environment at the workplace and also offers the opportunities for engaging GHRM as an effective strategy for organisations in discharging their corporate social responsibility on the environment to prevent future degradation and contamination.

\section{BIBLIOGRAPHY}

1. Alvarado, R., \& Toledo, E. (2017), Environmental degradation and economic growth: Evidence for a developing country. Environment, Development and Sustainability, 19(4), 1205-1218.

2. Anstätt, K., \& Volkert, J. (2016). Corporate Social responsibility impacts on sustainablehuman development. Ekonomskivjesnik/Econviews- Review of Contemporary Business, Entrepreneurship and Economic Issues, 29(1), 193-210.

3. Berry, M. A. \& Rondinelli, D. A., (2000), Environmental citizenship in multinational corporations: Social responsibility and sustainable development. European Management Journal, 18(1), 70-84.

4. Chandler, G. (2001). Defining corporate social responsibility," Ethical performance best practise, Fall 2002, cited in "What is corporate social responsibility? Catalyst Corporation and U.S. Agency for International Development (USAID).

5. Elkington, J. (1997). Cannibals with forks: the tripple bottom line of the 21 st century. Oxford: Capstone Publishing.

6. Elkington, J. (1998). Cannibals with forks: The triple bottom line 21 st century business. Gabriela Island, BC: New Society Publishers.

7. European Commission, (2001),Promoting a European framework for corporate social responsibility. Green Paper. http://europe.eu.int/comm/employment_soc $\mathrm{ial} / \mathrm{soc}-d i a l / c s r / c s r 2002$ en.pdf.

8. GRI (2011). Sustainability Reporting Guidelines: G3.1 version. Retrieved from http://globalreporting.org on 10th June, 2016.

9. Haddock-Millar, J., Sanyal, C., \& MüllerCamen, M. (2016), Green human resource management: a comparative qualitative case study of a United States multinational corporation. The International Journal of HRM 27(2), 192-211.

10. Hopkins, M. (2007). Corporate Social Responsibility: An Issues Paper. Working Paper No. 27, World Commission for Social Dimension of Globalisation, ILO, Geneva. Available from http://www.ilo.org/wcmsp5/groups/public/--dgreports/---integration/ documents/publication/wcms_079130.pdf. Accessed: 1st December, 2016.http//www.EzineArticles.com

Accessed: 1st December, 2020.

11. Islam, R., \& Uddin, M. M. (2016), Green HRM: Goal Attainment through Environmental Sustainability. Journal of Nepalese Business Studies, 9(1), 14-19.

12. Institute of Directors of Southern Africa (IOD), (2009). King Code of Governance for South Africa. Johannesburg: Institute of Directors of Southern Africa.

13. Jonikas, D. (2012). Value creation through CSR at stakeholders level. Economics and management, 17(2), 693-698.

14. Kavid, T.\&Watson, K. (2014), Green HR: an ideology or Practice in Possibility, Journal of Business Sustainability, 6 (2): 129- 39.

15. Kennedy, K \& Toffler, B (2014), Sustainable Management and Business Sustainability: Conceptual Models, International Journal of Business Strategy, 4(2): 45-67.

16. Kim, C., \& Scullion, H. (2013). The effect of Corporate Social Responsibility (CSR) on employee motivation: A cross-national study. Poznań University of Economics Review, 2013, 13(2), 5-30 [online] Available at: http://www.puereview.ue.poznan.pl/2013v1 3n2/1_Kim_Scullion.pdf [Accessed 6th December, 2020. 
17. Marrewijk M. \& Were, M. (2003) Multiple levels of corporate sustainability. Journal of Business Ethics 44(2), 107-19.

18. Mate, K. (2002) Capacity Building and Policy Networking for Sustainable MineralBased Development, Report prepared for UNCTAD under Project $M$ of the UN Development Account. Available at http://www.naturalresources.

org/minerals/latam/monterrey.htm Accessed 23rd December, 2020.

19. Mirfazli, E. (2008). Corporate social responsibility information disclosure by annual reports of public companies listed at Indonesia Stock Exchange (IDX). International Journal of Islamic and Middle Eastern Finance and Management, 1(4), $275-284$.

20. OECD. (2001). Corporate governance principles: OECD - Organisation for economic cooperation and development. OECD - Steering group on corporate governance. http://www.oecd.com.

Accessed 13th December, 2020.

21. Olanipekun, L.O., (2020): Green Human Resource Management as a 21st Century Tool for Achieving Sustainable Development and Competitive Advantage among Manufacturing Firms in Nigeria. Hallmark University Journal of Management and Social Sciences (HUJMSS).Vol. 2(3), pp. 112-130, October 2020.

22. Olanipekun, W.D (2019). Corporate Social Responsibility and Organisation Performance of Selected Nigerian Banks and Manufacturing Firms. Ann Arbor, Michigan, USA, ProQuest LLC.

23. Peter, B. \& Lanos, T., (2015), Introduction to Sustainable HR and Implications in Business Sustainability, International Journal of Management and Commerce, 6(2): 45-78.
24. Rupp, D., Ganapathi, J., Aguilera, R., \& Williams, C. (2006). Employee reactions to corporate social responsibility: An organizational justice framework. Journal of Organizational Behaviour, 2(7), 537-543.

25. Shaikh, M. (2010). Green HRM, A REQUIREMENT OF 21ST CENTURY. Journal of Research in Commerce and Management, 1, 122-127

26. Sharma, K. (2016). Conceptualization of Green HRM and Green HRM Practices: Commitment to Environment Sustainability.

27. Ullah, M. (2017). Integrating environmental sustainability into human resource management: A comprehensive review on green human resource management. Maghreb Review of Economics and Management, 4(1), 6-22.

28. Strandberg, C. (2009). The role of human resource management in corporate social responsibility: issue brief and roadmap. Report for Industry Canada, 20, 10-26.

29. World Business Council for Sustainable Development, (2002). Business case for sustainable development: Making a difference towards the Johannesburg Summit 2002 and beyond. Available on: http://www.wbcsd.org/DocRoot/rZNj49UF 0okxGvdLfDte/business-case.pdf. Accessed 10th December, 2020.

30. World Business Council for Sustainable Development, (2000). Corporate social responsibility, meeting changing expectations. Geneva, Switzerland.

31. Young, S., \& Thyil V. (2009). Governance, employees and CSR: Integration is the key to unlocking value. Asia Pacific Journal of Human Resources 47(2), 167-85.

32. Zadek, S. (2004). The path to corporate social responsibility. Harvard Business Review, 8(2), 125-132. 